\title{
THE CONSTITUTIONAL CONTEXT OF CANADIAN WATER PLANNING
}

\author{
DALE GIBSON*
}

\begin{abstract}
Water resource management in Canada involves both the federal and provincial constitutional powers. The result has been a complex administration which is both poorly co-ordinated and confusing. In order to explain the features of the present structure the author examines the federal and provincial powers involved. He concludes by advocating the replacement of federal and provincial control by a basin-oriented system of resource management which is feasible under the existing constitution.
\end{abstract}

\section{INTRODUCTION}

A newcomer to Canadian fresh-water ${ }^{1}$ management encounters a bewilderingly complex administrative galaxy. Boards and agencies without number, some in spendid solitude and others attended by many satellites, orbit endlessly without apparent heed for the others. Great unaccountable voids are occasionally to be seen, and the basic organizing pattern, if one exists, is difficult to discern. ${ }^{2}$

Much of the blame for this complexity has been laid on the Canadian constitution. To a large extent, this is justified. The subject of waterresource management straddles the two groups of constitutional powersfederal and provincial-created by the British North America Act, and a study of these powers can explain many features of the present administrative structure. It would be wrong, however, to assume that all the confusion and inefficiency that marks the existing structure is inevitable unless the constitution is amended. I hope to show that virtually any kind of improved administrative structure that water managers are likely to desire is capable of being created under the present constitution.

It must be understood, though, that guaranteed answers cannot be provided for the problems to be examined in this paper. Most law is opinion, and that is particularly true of constitutional law. Many questions of water law have never been considered by the courts, ${ }^{3}$ and many of the answers offered here are merely guesses at what the courts will hold when the occasion arises. Other writers have made guesses about many of these matters before, ${ }^{4}$ but not always to the same effect.

- B.A., LL.M. (Harvard). Professor of Law, University of Manitoba. This article was written for the Canadian Council of Resource Ministers, as a background paper for its 1968 Water Workshop Seminar.

1 This paper is restricted to inland waters.

2 An excellent outline of the principal agencies in charge of Canadian water resources is contained in the Canadian Council of Resource Ministers publication, The Administration of Water Resources in Canada, 1966. For an earlier survey, see Patterson, "Administrative Framework for Water Management," 1 Resources for Tomorrow Background Papers 227 (1961).

3 An attempt to settle a number of these problems by means of a constitutional reference to the Supreme Court of Canada was largely inconclusive: Reference Re Waters and Water Powers, [1929] S.C.R. 200.

4 The following have been most helpful to me: Laskin. "Jurisdictional Framework for Water Management." 1 Resources for Tomorrow Background Papers 211 (1961): Gisvold, A Survey of the Law of Water in Alberta, Saskatchewan and Manitoba (1956): Connolly, "The Problem of the South Saskatchewan River Development Project," Report of the Royal Commission on the South Saskatchewan River Project 159 (1952); Goldenberg, "Legal Aspects of the South Saskatchewan River Development Project," Id., at 168; Mackenzie, Interprovincial Rivers in Canada: A Constitutional Challenge (1961), 1 U.B.C.L.R. 499; La Forest. "Quebec's Property Rights in its Waters," in La Forest and Brossard. Territoire. Institute de Recherche en Droit Public. Université de Montréal, 1964 (soon to be published in French by Les Presses de l'Université de Montréal): and McGrady, Jurisdiction for Water Resource Development (1967), 2 Man. L.J. 219. In addition to these published works, I have also received much assistance 
The paper consists of three sections: "proprietary rights," "legislative rights," and "the future."

\section{PROPRIETARY RIGHTS}

It is important at the outset to distinguish between ownership of water rights and legislative jurisdiction over water. ${ }^{5}$ It is true that the matters are related; we shall see that ownership can be the basis of some legislative jurisdiction, and that legislative jurisdiction can give the power to affect ownership rights to a certain extent. But it must be kept in mind that legislative jurisdiction does not in itself bestow ownership, and that ownership does not grant automatic immunity from legislation.

The following discussion will deal separately with two different types of water resource: (a) those which lie entirely within provincial boundaries, where the competing claims involve the federal and provincial Crowns; and (b) those which cross provincial boundaries, where the rights of two or more provincial Crowns may be in conflict. Those which cross the international border, and therefore involve the rights of the United States, would logically comprise a third category, but because the issues are international rather than constitutional in nature, they are beyond the scope of this study.

\section{Intra-Provincial Waters}

Here we will examine the rights of the provincial and federal Crowns in turn.

\section{Provincial Rights}

The provinces are entitled to substantial proprietary rights related to water. For most provinces, these rights are founded on section 109 of the British North America Act, ${ }^{6}$ which states that, with certain exceptions, "all lands, mines, minerals, and royalties" which were publicly-owned before Confederation "shall belong to" the provinces. Matters are somewhat more complicated in the four western provinces, but the result is much the same. Until 1930, the Dominion owned and administered all public lands in the Prairie provinces, as well as those within the "Railway Belt" which British Columbia conveyed to the Dominion in accordance with the Terms of Union under which British Columbia entered Confederation. ${ }^{7}$ In that year, however, these rights were, with a few exceptions, transferred to the provincial Crowns by an amendment to the British North America Act giving constitutional force to transfer agree-

from a number of so far unpublished studies completed under the auspices of the University of Manitoba Interdisciplinary Study on Water Resources in Western Canada: Turnbull, Survey of the Political Aspects of Water Utilization; Hanssen, Constitutional Problems of Inter-Provincial Rivers, The Federal Declatory Power Under the British North America Act, and Constitutional Aspects of Federal Spending Power; and Pitch, The Treaty-Making Power and the Provinces, Provincial Proprietary Rights and Federal Legislative Jurisdiction and Constitutional Issues in Gas and Oil: An Anology.

5 ". . there is a broad distinction between proprietary rights and legislative jurisdiction. . . There is no presumption that because legislative jurisdiction was vested in the Dominion Parliament proprietary rights were transferred to it.": Per Lord Herschell in the Provincial Fisheries Reference, [1898] A.C. 700, 709.

- 1867, 30 and 31 Vict., c. 3. To the same effect is section 117, which states that the provinces "shall retain all their respective public property."

i Manitoba-Manitoba Act, S.C. 1870, c. 3, s. 30.

Saskatchewan-Saskatchewan Act, S.C. 1905, c. 42, s. 21

Alberta-Alberta Act, S.C. 1905, c. 3 .

British Columbia-Terms of Union between Dominion of Canada and British Columbia, S. 11; 
ments between the Dominion and the four provinces. ${ }^{\mathrm{x}}$ In the case of the prairie provinces, these agreements expressed in the first section the intention to place the province concerned "in the same position as the original Provinces of Confederation are in virtue of section 109 of the British North America Act, 1867." In fact, the position of the prairie provinces is not identical to that of the other provinces-a number of special provisions were found necessary in each of the agreementsbut the situations are sufficiently similar to be treated alike for the purposes of this discussion.

It will be noted that section 109 mentions only lands and minerals; no reference is made to water, ${ }^{10}$ or to other natural resources, such as fish. The reason for this is that the law has never recognized ownership of such commodities while they remain in their natural state. ${ }^{11}$ To become the "owner" of a quantity of water or of a fish, it must be reduced to possession, as by capturing water in a pail, or a fish in a net. This is not to say that there can be no legal-rights over water or fish in the natural state. Various rights of exploitation of water and its contents accrue to those who own the land underlying or adjacent to the water. ${ }^{12}$ Therefore, by giving the provinces the ownership of public lands, section 109 also conveyed to them plenary Crown rights in the water upon those lands, ${ }^{13}$ and the fish therein. ${ }^{14}$

The exact extent of these provincial Crown rights, being generally within the control of the provincial legislatures, is outside the scope of this essay. Nevertheless, a brief summary of the general legal principles applicable in the absence of legislation might be helpful as background information. ${ }^{15}$

A distinction must be made, first, between water rights exercisable by the general public, and those which arise from the ownership of land.

8 British North America Act, 1930, 20-21 Geo. 5, c. 26.

0 The British Columbia agreement contained no such provision, presumably because s. 109 always applied to that province, the Railway Belt having been transferred to the Dominion some years after British Columbia entered confederation.

10 The transfer agreements for the three prairie provinces were at their request amended in 1938 to state expressly that they included "the interest of the Crown in the waters and water-powers within the Province" as defined by certain federal statutes: The and water-powers within the Province" as defined by certain federal statutes: The Alberta and Saskatchewan was apparently caused by the fact that whereas the provisions of the Alberta Act and Saskatchewan Act which originally vested resource rights in the federal Crown expressly referred to water rights, the transfer agreements did not. Manitoba's fears are not as easy to understand, since the pertinent section in the Manitoba Act did not mention water.

11 Embrey v. Owen (1851), 6 Ex. 369. The civil law of Quebec does not appear to differ significantly from the common law of the other provinces in this respect. Miner v. Gilmour (1858), 12 Moo. P.C. 131, 156. Indeed, the United States Supreme Court has suggested that the origins of the notion are to be found in civil law:

As long ago as the Institutes of Justinian, running waters, like the air and the sea, were res communes-things common to all and property of none. Such was the doctrine spread by civil-law commentators and embodied in the Napoleonic Code and in Spanish law. This conception passed into the common law. From these sources, but largely from civil-law sources, the inquisitive and powerful these sources, but largely from civil-law sources, the inquisitive and powerful
minds of Chancellor Kent and Mr. Justice Story drew in generating the basic doctrines of American water law.

United States v. Gerlach Live Stock Co. (1950), 339 U.S. 725, 744-5, per Jackson, J.. quoted in 1 Clark, Waters and Water Rights, 34-35 (1967).

12. These rights are of a type sometimes called "usufructory": rights of use. They vest no ownershlp in the commodity with respect to which they are granted, but they no ownership in the commodity with respect to which they are granted. but they to possession, and, paradoxically, the right of use itself is legally capable of ownership. Thus, a usufructory right to fish in a certain portion of a river would not automatically make the holder of the right the owner of any fish, but it would entitle him to become the owner of fish by catching them; and he could sell the usufructory right, or dispose of it in any other way he could dispose of his property.

13 The Privy Council held, in Burrard Power Company v. R., [1911] A.C. 87, 94, that the British Columbia grant to the Dominion of "public lands" in the Railway Belt "undoubtedly passed the water rights incidental to those lands."

14 Provincial passed the water rights incidental

15 This summary is based on Professor Bora Laskin's study, op. cit. supra, n. 4, at 212; Gisvold, op. cit. supra, n. 4; and Clark, op. cit. supra, n. 11, at ch. 3. 
In the first catetory is the right of any member of the public to navigate and to fish in certain waters regardless of who owns the bed or the adjacent land. By English common law, this applies only to tidal waters, but because North America contains so many important inland waterways, American and Canadian courts have extended the public right of navigation to all navigable waters, whether or not tidal. ${ }^{16}$ The public right to fish does not seem to have been extended in a similar way. ${ }^{1 i}$ These public rights of navigation and fishing may not be taken away by provincial legislation. ${ }^{18}$

Other water rights are based on land ownership. The Crown's rights fall into this category, and do not differ very much in kind (though they do in extent) from those of private landowners. The owner of land has, at common law, the right to extract as much ground water from the property as he pleases, regardless of detrimental consequences to his neighbours. ${ }^{19}$ If the land borders on surface water, he has rights to that water also, but they are not as extensive as those over ground water; he is entitled to have access to surface water, and to use it for any purpose which does not substantially injure other riparian owners. ${ }^{20}$

If he owns part of the bed of the lake or stream he also acquires the exclusive right to fish over that portion of the bed, at least where the water is not navigable, and probably wherever it is not tidal. One may acquire ownership of the bed by express grant from the Crown, or by purchase from someone whose title is based on such a grant. Where the conveyance of land does not mention the matter, it is presumed by English law that bed ownership is reserved to the Crown if the water is tidal, but that ownership to the mid-point of the stream is vested in the adjoining landowner if the water is non-tidal. In most Canadian provinces it is likely that this principle has been varied by extending the presumption of Crown ownership to the beds of all navigable waters, rather than just tidal waters. ${ }^{21}$ All of this is of chiefly academic interest,

11 Fort George Lumber Co. v. Grand Trunk Pacific (1915), 24 D.L.R. 527 (B.C.S.C.). "Navigable" is given a quite broad interpretation: ". . in order to give it the character of a navigable stream it must be generally and commonly useful to some
purpose of trade or agriculture,": Keewatin Power Co. v. Town of Kenora (1906), 13 O.L.R. 237, 243, per Anglin, J. (quoting from an American case). As the above case illustrates, the floating of logs for lumber operations is regarded as navigation. The legal power to vary the English rule is the proviso in the various statutes introducing English law into the provinces to the effect that principles that are not "applicable" to local circumstances are not included: Clarke v. Edmonton, [1930] S.C.R. 137, 149.

17 Laskin op cit. supra n. 4 , says that "there is some opinion that the public have a right to fish in navigable waters if title to the bed is in the Crown and not in a private person." but that "the burden of authority puts the right no higher here than in England."

18 A.-G. for Canada v. A.-G. for Quebec, |1921| 1 A.C. 413.

19 Except in the rare case where the ground water takes the form of an underground stream, flowing in a defined channel, in which case the principles appropriate to surface streams are applicable.

20 This is a gross over-simplification. The task of determining which types of use by riparian owners are legitimate is a difficult one. Laskin, op. cit. supra, n. 4, at 213 . points out that the courts seem divided on whether any interference with the natural flow of the stream is an injury of which another riparian owner may complain, or whether it must be an unreasonable interference, with the weight of authority favoring the latter approach.

21 Laskin op cit. supra n. 4, points out that it would be "incredible to apply the English rule . to the Great Lakes" and asserts that with the possible exception of British Columbia, the presumption of private bed ownership applies only to nonof British Columbia, the presumption of private bed ownership applies only to non-
navigable waters in Canada. He cites Leamy v. The King (1916), 54 S.C.R. 143, which is authority for Quebec, and Clarke v. Edmonton, supra, n. 16, in which a similar principle for Alberta was assumed by the court for the purpose of argument, but not decided. Two years later, the Supreme Court of Canada held, in The King v. Fares, [1932] S.C.R. 78, that the common law presumption of private bed ownership does not even apply to non-navigable waters in a part of Northwest Territories which later became Saskatchewan, because, inter alia, federal legislation befreries which later sistent with the English principle. Laskin's proviso respecting British Columbla was probably based on the dictum of Viscount Haldane in A.-G. for British Columbia v. A.-G. for Canada, [1914] A.C. 153, to the effect that the English rule applies to non-tidal waters in that province. If the dictum is accepted, however. it is difficult to see why it should not apply to all common law provinces. 
however, since the legislature of each province may alter the law as it sees fit, and this power has been exercised frequently. Alberta, for example, has, by retroactive legislation, abolished all private bed ownership. ${ }^{22}$

It is important to remember that the property rights given to the provinces by section 109 are "subject to any trusts existing in respect thereof, and to any interest other than that of the province in the same." This means, for example, that the province has no right to affect the title to Indian reservation land existing at the time of Confederation, although it has the reversionary right to ownership of the land when Indian rights are relinquished..$^{23}$

Of course, section 109 is not the only basis of provincial property rights. The provincial Crown may, like anyone else, also acquire property by purchase.

\section{Federal Rights}

The proprietary rights of the federal Crown, although not as great as those of the provinces, are nonetheless considerable. To begin with, section 108 of the British North America Act states that: "The public works and property of each province, enumerated in the third Schedule to this Act, shall be the property of Canada." Included in the schedule referred to are several items that have a bearing on water resource planning:

1. Canals, with lands and water power connected therewith.24

2. Public harbours. ${ }^{25}$

3. Lighthouses and piers, ...

4. Steamboats, dredges, and public vessels.

5. Rivers and lake improvements. 26

10. ... lands set aside for general public purposes. ${ }^{27}$

This section applies only to the original confederating provinces, plus British Columbia and Prince Edward Island..$^{28}$ The property transferred from Newfoundland ${ }^{29}$ and the prairie provinces $^{30}$ to Canada was con-

22 Public Lands Act, R.S.A. 1955, c. 259, s. 5(2).
23 Ontario Mining Co. v. Seybold, [1903] A.C. 73 .

24 This has been interpreted to create proprietary rights only to the canals themselves: ". It does not follow that because the several canals are public works that the portions of the St. Lawrence River which lie between such canals are also public portions of the St. Lawrence River which lie between such canals are also public the Dominion any proprietary rights in the river from which the water is taken, beyond the right to take the water. . .": Macdonald v. The King (1906), 10 Ex. C.R. 394, 400-1.

25 There has been much litigation over the meaning of this clause. See La Forest, The Meaning of "Public Harbours" in the Third Schedule of the British North America Act, 1867 (1963), 41 Can. Bar Rev. 519.

20 'The awkward phraseology of this clause led some to believe that it conveyed ownership of all rivers in their entirety to the federal Crown, but the Privy Council decided in The Fisheries Reference, supra, n. 5, that it should be construed as if it read "river improvements and lake improvements."

27 La Forest, op. cit. supra, n. 4, at 6 , has pointed out that this does not apply to navigable waters generally. Such an argument was raised before the Supreme Court of Canada in The Provincial Fisheries Reference, but rejected by that court without comment.

28 La Forest, loc. cit. supra, n. 25, at 519. In the case of British Columbia, certain additional property came under federal ownership by virtue of the 1930 resources transfer agreement: certain wharves and harbours, Indian Reserves, National Parks, Soldier Settlement Lands, pre-existing Crown reservations, etc.

29 Section 33 of the Terms of Union of Newfoundland with Canada (approved S.C. 1949, c. 1) transfers to Canada the following property, inter alia " (d) public harbours, wharves, breakwaters and aids to navigation ... (g) public dredges and vessels," (with certain exceptions) and " $(j)$. . generaily all public works and property, real and personal, used primarily for services taken over by Canada," (with certain excepand perst

30 The Alberta and Saskatchewan Acts both contain sections (section 22 in both Acts) stating that "all properties and assets of the Northwest Territories shall be divided equally" between the two provinces. The Manitoba Act does not have any equivalent provision, but it is doubtful that any public property of the type listed in section 108 existed in 1870 which was not already owned by the federal Crown. The resource 
siderably different. Even in the provinces where it is applicable, the section only covers items of public property which were in existence at the time the section came into force. ${ }^{31}$

In addition to section 108 and its equivalents, there are several other ways by which the federal Crown may acquire property rights over water. In the non-provincial territories, the federal Crown has the same rights that a province enjoys within its own boundaries. Section 117 of the British North America Act establishes: "the right of Canada to assume any lands or public property" in a province if "required for fortifications or for the defence of the country." The courts have also recognized a similar federal expropriation power, even over provincial Crown property, in connection with other federal activities, such as railways. ${ }^{32}$ Finally, of course, the federal Crown can acquire property by purchase like anyone else.

\section{Inter-Provincial Waters}

There are many important inter-provincial bodies of water in Canada. Some, like the Ottawa River, partially define the boundary between two provinces. Others, like the Saskatchewan River, run through the territory of two or more provinces. Even ground water can be interprovincial; there is, for example, a slow but inexorable movement of ground water from Alberta, through Saskatchewan, to Manitoba. This section is concerned with the problems that arise when uses are made of an interprovincial water in one province which have detrimental consequences in another province: as where pollution entering the Ottawa River from the Ontario side causes damage in Quebec, or irrigation schemes in Alberta divert so much water from the Saskatchewan that power generation in Manitoba is adversely affected, or pumping brine from potash-mining operations into the ground in Saskatchewan jeopardizes Manitoba's ground water supply.

When problems of this kind are discussed by water administrators, it is frequently in terms of another, more general question: who owns inter-provincial waters? I hope that enough has already been said about the nature of Crown water rights that this approach can clearly be seen to be unproductive. Water in the natural state is not capable of ownership, either as between individual riparian land owners, or as between neighbouring provinces. It is conceivable, of course, that some form of inter-provincial ownership might be created by inter-provincial agreement or possibly by federal legislation, but until this occurs the law will concern itself only with the respective rights of use of the riparian provinces.

Unfortunately, no description of inter-provincial rights in this area can be made with confidence. The British North America Act contains nothing of assistance, and there has been no Canadian litigation on the subject. However, it is a fundamental principle of our legal system that every legal problem has an answer. If a dispute of this type were placed

transfer agreement of 1930 preserved several federal ownership rights, however: Indian Reserves (in trust only) Soldier Settlement Lands, National Parks, pre-existing Crown reservations, etc.

31 See, for example, Reference re Waters and Water Powers, supra, n. 3, at 202, where the Supreme Court of Canada held that federal proprietorship under section 108 of water power connected with canals does not include any created by post-Confederation improvements.

32 A.-G. for Quebec v. Nipissing Central Railway, [1926] A.C. 715. 
before a court it would be obliged to find some solution. The following is an attempt to decide what solution would likely be reached in the absence of relevant agreements or legislation.

The problem has two quite distinct aspects: procedural, and substantive. Procedurally, it is necessary to determine which forum has jurisdiction to settle inter-provincial rights, and the machinery by which the matter can be brought before that forum; substantively, the principles of law on which a decision would likely be based must be discussed.

On the procedural side, the first thing to be done is to dispose of the fallacious contention that one province may not sue another, or the federal Crown, because the Crown is "one and indivisible." It has been argued by some that since the Queen is the same person whether acting in the right of Australia, or Canada, or Nova Scotia, or British Columbia, a legal action between any of those jurisdictions would'require the Queen to sue herself, which is an absurdity, and a legal impossibility. ${ }^{33}$ This argument has been punctured by Gisvold, who shows that in constitutional law, as in private law, it is possible for a person acting in one capacity to entertain an action against himself in another capacity. ${ }^{84}$ Professor Laskin has expressed a similar opinion:

... there is no obstacle to resolution of competing proprietary water rights by reason of the anachronistic concept of indivisibility of the Crown. The Crown in the right of one Province is different from the Crown in the right of another or from the Crown in the right of Canada. . . ..$^{35}$

A second procedural problem is to determine the appropriate court to hear inter-jurisdictional disputes, but again it raises few practical difficulties. The federal Parliament has provided, in section 30 of the Exchequer Court Act, ${ }^{36}$ that disputes of this kind may be decided by the Exchequer Court (with appeal to the Supreme Court of Canada) if the provinces involved have passed legislation accepting the arrangement. It is true that this is a purely voluntary scheme, but in fact all but two provinces have passed legislation submitting to the Exchequer Court's jurisdiction. ${ }^{37}$ Even in the case of the two provinces which have not done

33 See, for example, Connolly, op. cit. supra, n. 4, at 166: “" . there can be no rights between the provinces with reference to Crown property, because the owner in each case is Her Majesty, and she cannot have rights against Herself."

34 Op. cit. supra, n. 4, at 99-101. His principal authority is Re Silver Brothers, [1932] A.C. 514, 524, in which the Privy Council pointed out: "It is true that there is only one Crown, but as regards Crown revenue and Crown property by legislation assented to by the Crown there is a distinction made between the revenues and property in the by the Crown there is a distinction made between the revenues and property in the statutory purses. In each the ingathering and expending authority is different." See also dictum of Lord Loreburn, L.C., in Dominion of Canada v. Province of Ontario, [1910] A.C. 637, 645.

35 Laskin, op. cit. supra, n. 4 at 223. See also, Mundell, Legal Nature of Federal and Provincial Executive Governments (1960), 2 Osg. Hall L.J. 56, 70 ff.

Two other theoretical ways around this problem would be to commence actions either in the name of the Attorney-General of the plaintiff province, or in the name of the in the name of the Attorney-General of the plaintiff province, or in the name of the
province itself (on the theory that the B.N.A. Act, by creating the Dominion and the provinces and giving them rights and obligations, impliedly gave them also corporate personality) instead of in the name of the Crown. On the latter point, see the comment of Dixon, J., of the Australian High Court, in Bank of N.S.W. v. The Commonwealth (1948), 76 C.L.R. 1, 362: "the Constitution sweeps aside the difficulties which might be thought to arise in a federation from the traditional distinction between, on the one hand the position of the Soverelgn as the representative of the State in a monarchy, and on the other hand the state as a legal person in other forms of governmonarchy, and on the other hand the state as a legal person in other forms of govern-
ment. . . From beginning to end it treats the Commonwealth and States as organizations or institutions of government possessing distinct individualities."

36 R.S.C. 1952 , c. 259.

37 Alberta-S.A. 1965, c. 29.

British Columbia-R.S.B.C. 1960, c. 141

Manitoba-R.S.M. 1954 , c. 51 .

New Brunswick-R.S.N.B. 1952, c. 83.

Newfoundland-S.Nfld. 1954, c. 13.

Ontario-R.S.O. 1960, c. 112.

Prince Edward Island-R.S.P.E.I. 1951, c. 79, s. 40

Saskatchewan-R.S.S. 1953, c. 71 . 
so, Quebec and Nova Scotia, it is probable that if a dispute arose there would be agreement to submit the dispute to some mutually agreeable forum. $^{98}$

In the unlikely event that a province refused to submit to the jurisdiction of any court, several ways of forcing it to do so are open. It would be theoretically possible for the legislature of the plaintiff province (which has the power to determine provincial conflict of laws rules) to pass a law enabling the defendant province to be sued in the courts of the plaintiff province, ${ }^{39}$ but such a procedure would be both practically ineffective and politically questionable. I believe, as will be seen in the section on legislative powers, that it would also be possible for the federal Parliament to create compulsory jurisdiction in the Exchequer or Supreme courts to determine inter-jurisdictional disputes. The easiest way to sue the unco-operative province, however, would be in many cases simply to bring an action against it in its own courts. ${ }^{40}$ In some provinces the law provides that the Crown may not be sued without its consent, or that it cannot be held legally liable for alleged wrongs. In provinces where there are no such legal impediments, however, an action of this type would have a fair chance of success. The major problem would be that the law of the defendant province might well have legalized the activity complained about, but as I hope to show in the discussion of the substantive law applicable, this might not be an insuperable obstacle.

In short, the procedural difficulties involved in inter-jurisdictional legal disputes over water rights are not as formidable as they are sometimes made out to be.

The substantive question-What legal principles govern inter-jurisdictional water disputes?-is not so easy to answer. Neither the British North America Act nor the Exchequer Court Act offers any assistance.

The first thing to be decided is whether the applicable law would be that of one or other of the jurisdictions involved, or whether instead the court could create a kind of "constitutional common law" whose principles would be appropriate only to inter-jurisdictional litigation. I submit that the preferable approach is the latter one. Those who fear judicial creativity would probably favour the first approach, but in fact the court cannot avoid being creative. If in adjudicating a dispute between Saskatchewan and Alberta over pollution of the Saskatchewan River the court wished to avoid creating special "common law" rules, it would nevertheless have to decide the basis for choosing to apply the law of Alberta or that of Saskatchewan. There are conflict of laws theories that would lead to either result, so the court would have to be creative, at least to the extent of deciding what its conflict of laws rules are to be for this kind of case. More important, to take this approach would in itself create the principle that inter-jurisdictional disputes are

38 In Nova Scotia, for example, there is provision in the Constitutional Questions Act. R.S.N.S. 1954, c. 50, to allow the Lieutenant-Governor in Council to submit such cases to the provincial Supreme Court, from which there would be the normal rights of appeal, including appeal to the Supreme Court of Canada.

30 Laskin, op. cit. supra, n. 4, at 222, disagrees.

40 In Albert v. Fraser Companies Ltd., [1937] 1 D.L.R. 39, the Appellate Division of the New Brunswick Supreme Court held, Harrison, J., dissenting, that New Brunswick courts did not have jurisdiction to entertain a claim against a New Brunswick resident for damage caused by flooding of land in Quebec as a result of a river obstruction in New Brunswick. However, as Laskin says, op. cit. supra, n. 4, at n. 62, "the result is hardly satisfactory." The case seems to me to be clearly wrong. 
to be decided on the basis of the laws of one party to the litigation. Since the court cannot escape being creative in one way or another, is it not desirable that the principles it creates be designed to deal with interjurisdictional disputes as fairly as possible? And surely it is not fair to allow one party to a dispute to dictate the laws by which the dispute is to be settled? If they are to play a significant role in the determination of inter-jurisdictional disputes, the courts must be acknowledged to have the power to create a special "constitutional common law" uniquely applicable to inter-governmental legal relations.

There is a passage from a Privy Council decision which could be read as conflicting with this view. It occurs in the opinion given in an action between Canada and Ontario under the equivalent of section 30 of the Exchequer Court Act." Canada had negotiated a surrender of certain Indian reservation lands in Ontario in return for a cash settlement. Since ownership of the surrendered lands reverted to the Crown in the right of Ontario, Canada demanded compensation from Ontario for the benefit thereby bestowed on the province. The Privy Council rejected this claim, on the ground that there was no known legal principle upon which it could succeed. Lord Chancellor Loreburn stated, in part:

Their Lordships are of opinion that in order to succeed the appellants must bring their claim within some recognized legal principle. The Court of Exchequer, to which, by statutes both of the Dominion and the province, a jurisdiction has been committed over controversies between them, did not thereby acquire authority to determine those controversies only according to its own view of what in the circumstances might be thought fair. It may be that, in questions between a dominion comprising various provinces of which the laws are not in all respects identical on the one hand, and a particular province with laws of its own on the other hand, difficulty will arise as to the legal principle which is to be applied. Such conflicts may always arise in the case of States or provinces within a union. But the conflict is between one set of legal principles and another. In the present case it does not appear to their Lordships that the claim of the Dominion can be sustained on any principle of law that can be invoked as applicable.

The statement that "the conflict is between one set of legal principles and another" could mean that the court must choose between the established laws of one or another party to the action, rather than determining its own "common law" principles. ${ }^{42}$ Read in conjunction with the comment that the court may not decide such cases "only according to its own view of what in the circumstances might be thought fair," however, a second interpretation is possible: that the court's decisions must be based on law rather than pure discretion. That principle is entirely compatible with the opinion urged above, and in view of the fact that the other interpretation would seem to deny the court even the essential power to create its own conflict of laws rules, I submit that this is the only way in which Lord Loreburn's remarks can realistically be interpreted.

Even if the "constitutional common law" theory were rejected, and the court held that inter-jurisdictional conflicts must be resolved on the basis of the law of one or other of the jurisdictions, a strong argument could be made to the effect that it is only the inherited law of the particular province at the date of its creation that could be used to defend claims from other jurisdictions, and not any provincial statute passed

$\$ 1$ [1910] A.C. 637, 644-5.

42 The statement of Duff. J., of the Supreme Court of Canada, in the same case, that "we should not presume that the Exchequer Court has been authorized to make a rule of law for the purpose of determining such a dispute" seems to carry such an implication: (1910) 42 S.C.R. 1, 118. 
to modify the law since that time. The basis of this argument is the principle of Canadian constitutional law that provincial legislatures do not have the power to enact statutes which seriously derogate from civil rights that would otherwise be enjoyed outside the province. For example, the Privy Council held in Royal Bank of Canada v. The King ${ }^{48}$ that money raised in England by a Montreal bank through the sale of bonds of an Alberta railway company, and held by the bank at its New York office, could not be validly confiscated by an Alberta statute, because the statute would be extinguishing rights outside the province (the right of the English bondholders to claim re-imbursement from the head office of the Montreal bank), which would be beyond the province's constitutional jurisdiction. This is not to say that no provincial statute may have consequences outside the province. Statutes conferring rights on persons outside the province are valid, ${ }^{44}$ as are statutes which encroach on extra-provincial rights in a merely incidental manner, in connection with some otherwise valid purpose.45 How would this principle apply to an Alberta statute authorizing a water diversion from the Saskatchewan River which had serious detrimental effects in the downstream provinces, or a Manitoba statute authorizing a power dam in the province which would cause flooding in upstream Saskatchewan? It would be possible to argue that such statutes would be valid, because they relate primarily to matters within the province and have only an incidental effect beyond the boundary. However, I think that the extraprovincial consequences of such legislation would probably be regarded as being of primary importance, and that it would accordingly be held to be ultra vires to the extent that it applied to inter-jurisdictional water disputes. ${ }^{46}$ Hence, even if a defendant province were allowed to raise its own laws in defence, they would not include any statutes passed since Confederation to diminish the rights of persons outside the province.

Returning to the more probable situation-that the courts would create a special "constitutional common law" to deal with these disputesthe next problem is to determine what principles the courts would be likely to adopt in developing this inter-jurisdictional law of water. Again, there are no authoritative guides, but it is highly probable that experience with similar controversies in the United States would provide useful analogies. ${ }^{47}$ The court would have a wide range of approaches open to it, from a Harmon Doctrine attitude that the upstream province has the unfettered right to use the water as it pleases, to an unqualified riparian theory that the downstream province has an absolute right to receive all of the natural flow, undiminished and unpolluted. The American courts seem to have settled on an "equitable apportionment" doctrine, whereby the court simply decides whether in the light of all the surrounding circumstances, a particular use of the water by one state is equitable. Equitable apportionment has never been a feature of Canadian private water law (except where introduced by legislation) and

43 [1913] A.C. 283

44 A.-G. for Ontario v. Scott, [1956] S.C.R. 137.

$45 \mathrm{Re}$ Ogal, [1940] 1 W.W.R. 665 .

46 Connolly, op. cit. supra, n. 4, at 167 agrees, but Laskin, op. cit. supra, n. 4, at 221 does not.

47 Many good descriptions of the principles governing inter-state water disputes in the United States exist, one of the best being 2 Clark, op. cit. supra, $\mathrm{n}$. 11. Two good studies of the relevance of American experience to Canada are: Goldenberg. op. cit. supra, n. 4 , at 168 , and Mackenzie, loc. cit. supra, n. 4 . 
is therefore unlikely to be overtly employed in settling inter-jurisdictional disputes in Canada. However, the riparian rights doctrine, which dominates the Canadian water law heritage has been marked in more recent years by a proviso allowing "reasonable use" by the upstream owner. It seems probable that a similar principle would be applied in interjurisdictional litigaton, with the result that, in the words of one writer:

... each of the provinces ... has legal rights to the reasonable use of the surface waters ...;... none of these provinces may dispose of such waters within its boundaries to the injury or prejudice of . . . other provinces. . . 48

This would not seem in practice to be very different from the equitable apportionment approach. It is doubtful that ground water would be treated in the same way, however. If the analogy to private law were followed, then the well-established, if unsatisfactory, rule that the upstream owner may extract all the water he pleases from wells on his own land would probably be applied (although there would probably be liability for polluting inter-provincial ground water by pumping waste into the ground.) ${ }^{49}$

Probably this inter-jurisdictional common law would only apply to litigation between governments. A private riparian owner could not make use of the Exchequer Court Act, and if he sued the party responsible for the act complained of (whether a private person or government agency) in the normal way, it is probable that the court would apply the law of the defendant's jurisdiction to the dispute. The same would be true if a government plaintiff sued a private defendant (whether suing in its own right as a riparian owner or on behalf of its injured citizens). However, since the constitutional rule that provincial statutes cannot seriously derogate from extra-provincial rights would still apply, the claimants might nevertheless have a strong case.

\section{LEGISLATIVE RIGHTS}

The power to make laws concerning water rights is also divided between federal and provincial authorities, although not in quite the same manner as proprietary rights. Federal powers are substantial in respect to all waters, but even greater in the case of inter-provincial and international waters.

\section{Provincial Rights}

\section{Intra-Provincial Waters}

The various types of legislative jurisdiction over water rights which the British North America Act gives to the provincial legislatures may be described very briefly, but it would be a serious mistake to assume that they are therefore unimportant.

A link between provincial proprietary and legislative rights is provided by section $92(5)$, which empowers the provincial legislatures to make laws relating to "the management and sale of the public lands belonging to the province." Apart from this, the most important heads of provincial jurisdiction are sections $92(13)$, "Property and civil rights in the province," and 92(16), "Generally all matters of a merely local or private nature in the province." Further jurisdiction can be founded on sections $92(10)$, "local works and undertakings . . ." (subject to 
certain exceptions), 92(8), "Municipal institutions in the province," and 95, "Agriculture in the province. ..."

The combined effect of these provisions is to give the provincial legislatures very sweeping law-making powers with respect to water resources in the province. It must be kept in mind, however, that there are several important limitations to these powers. Some of the provincial proprietary rights are subject to trusts (such as those relating to Indian lands) ${ }^{50}$ or public rights (such as the public right to fish in tidal waters) ${ }^{11}$ which may not be extinguished by provincial legislation. One of the most significant limitations is the principle we have already examined to the effect that no provincial statute may seriously encroach on rights beyond provincial boundaries. ${ }^{52}$ Another major restriction is the fact that agencies of the federal government or other provinces, ${ }^{33}$ companies engaged in extra-provincial undertakings, ${ }^{54}$ and, perhaps, all federally incorporated companies, ${ }^{55}$ are immune from provincial laws concerning "all matters which are a vital part"su of their operations. Moreover, the courts have never allowed provincial legislation to deprive the federal Crown of any of its proprietary rights, although they have allowed Parliament to confiscate provincially owned property. ${ }^{57}$ Another impediment to the full exercise of provincial legislative powers-a practical one-is the inability of many provincial governments to finance all the operations they have the constitutional power to carry out. This is not basically a constitutional limitation-the provincial power to impose direct taxation, as now interpreted, provides an ample source of revenues in theoryit is the result of two factors: that some provinces are not as well off as others, and that even the wealthy provinces find it difficult politically to impose adequate taxation because of the extent to which the federal government is already taxing the same taxpayers. Finally, it will be seen in the next section that there are many relevant heads of federal jurisdiction in this field, and these take priority over any of the sources of provincial jurisdiction, with the result that if a particular subject of legislation (such as bridges over rivers) can be said to concern both a matter under provincial control (say "local works and undertakings") and a matter under federal control (say "navigation"), a provincial statute on

so St. Catherine's Milling and Lumber Company v. The Queen (1889), 14 A.C. 46.

o1 A.-G. for British Columbia v. A.-G. for Canada, supra, n. 21; Canada v. A.-G. for Quebec, supra, n. 18.

62 Supra, n. 46.

53 Laskin, op. cit. supra, n. 4, at 222, goes so far as to say that a provinclal legislature "cannot bind the federal Crown by legislation," and there is a similar statement in a recent judgment of the Supreme Court of Canada: The Queen $v$. Breton (1968), 65 D.L.R. (2d) 76, 79. I hope to show that this is an exaggeration of federal immunity in an article soon to be published: "Interjurisdictional Immunity in Canadian Federalism."

54 Commission du Salaire Minimum v. Bell Telephone (1967), 59 D.L.R.(2d) 145.

55 British Columbia Power Corporation v. A.-G. of British Columbia (1963), 44 W.W.R. 65 (B.C.S.C.). I think this cese went tco far also: Gibson, The B.C. Power Case: New Restrictions on Provincial Control Over Federal Companies (1963), 1 Man. L.S.J. 155.

so Per Martland, J., supra, n. 45 , at 148.

si Laskin, op. cit. supra n 4, at 214, says: "“. it is quite clear that, whatever be the range of provincial legislative power in respect of water management. a Province cannot apply its legislation to federal Crown property. The reverse is not, however, true. Thus, Parliament may, in connection with its railway (and, indeed, interprovincial transport and communication) power expropriate or authorize expropriation by its licensees of provincial Crown land as well as of private land. A.-G. for Quebec v. Nipissing Central Railway, [1926] A.C. 715."

It should be noted that the principal argument employed in this case-that the power to legislate must, to be effective, include the power to affect proprietary rightswould seem equally applicable to provincial legislative jurisdiction. Section 125, which states that "No lands or property belonging to Canada or any province shall be liable to taxation" does not appear to have been ralsed in argument, yet if expropriation can be regarded as the ultimate form of taxation, it seems to me to be applicable. 
the subject would be valid only so long as no inconsistent federal statute were passed.s

\section{Federal Rights}

The federal government is currently involved in water management in a remarkably wide range of capacities. The reason for the richness of this involvement is partly to be found in the plenitude of federal constitutional powers over water. And these powers, it should be noted, are not subject to the many limitations that, we have just seen, restrict the exercise of provincial legislative power in this field.

Parliament's jurisdiction over "Navigation and shipping"so is one of its most important sources of authority over provincial water. Every body of water in Canada that can be navigated (even in such rudimentary ways as by floating logs), or can be made navigable, is thereby subject to exclusive federal control of all matters primarily concerning navigation and navigability. This means, for example, that provincial bridges, power dams, flood control projects, etc., must all conform to federal regulations to the extent that they affect navigation. This much seems well established. Where there is room for difference of opinion is over the extent to which Parliament may concern itself with matters which do not directly concern navigation, but which a multi-purpose approach to resource planning would require to be dealt with in conjunction with questions of navigation. There is a principle of constitutional law that a statute which deals primarily (in pith and substance) with a matter within the legislature's jurisdiction is valid, even if it "incidentally affects" a matter normally outside its jurisdiction. ${ }^{60}$ However, this applies only to incidental matters which are relatively minor compared to the main purpose of the legislation, and it is extremely doubtful that federal jurisdiction over the hydro aspects of a multi-purpose project could be justified simply because there is also a navigation aspect. There is not much authority on the subject in Canada, but what there is indicates that the navigation power will only justify federal jurisdiction over legislation primarily concerned with navigation itself. ${ }^{61}$

Parliament also has, by section 91(12), jurisdiction over "Seacoast and inland fisheries." There has been considerable litigation over the meaning of this power, the result of which, in general terms, is that the provincial legislatures have jurisdiction over all the proprietary and marketing aspects of fishing (granting of private rights to fish, deter-

58 See: Lederman, Concurrent Operation of Federal and Provincial Laws (1963), 9 McGill L.J., 185, and Laskin, Occupying the Field: Paramountcy in Penal Legislation (1963), 41 Can. Bar Rev. 234.

59 Section 91(10). Section 91(9) gives Parliament jurisdiction over "Beacons, buoys, lighthouses $\because "$ as well.

The best treatment of this subject that I have read is in Professor Laskin's paper, op. cit. supra, n. 4, at 216-218, and I have borrowed greedily from it in the following account.

60 Thus in A.-G. for Canada v. C.P.R. and C.N.R., [1958] S.C.R. 285, a section of the federal Railway Act relating to the ownership of minerals underlying rallway lines was upheld on the ground that it was necessarily incidental to federal railway legislation, even though it affected an area of law normally within provincial jurisdiclegislation.

61 Reference Re Waters and Water Powers, supra, n. 3, at 200, Laskin, op. cit. supra, n. 4, at 216-217, points out that in the United States the federal navigation power (which, paradoxically, is not specifically mentioned in the Constitution, but has been inferred from the inter-state commerce power) has been held to justify federal control over water power and other aspects of multi-purpose water management, and that there have been occasional hints of a similar approach in Canadian cases. He indicates, however, that in view of the extremely limited interpretation which the Canadian courts have given to the federal "Trade and commerce" power, it is highly unltkely that the American authorities will ever be followed here. 
mining the law of private fishing rights, processing and selling fish once caught, etc.), ${ }^{62}$ but that Parliament controls the regulatory aspects of fishing (determining fishing seasons, methods of fishing, conservation regulations, pollution measures, public fishing rights, etc.) ${ }^{63}$ Although the distinction is easy to state, it is very difficult to apply in many specific situations, of course. In practice, however, federal and provincial authorities seem to have reached satisfactory agreements concerning the division of responsibility.

There are several other heads of federal legislative jurisdiction which, while not individually as important as navigation or fisheries, comprise collectively a substantial reservoir of federal power. Like the provincial legislatures, Parliament derives some jurisdiction from its right (under section 91(1A), "The public debt and property") to legislate concerning federal proprietary rights. Since, as we have seen, federal proprietary rights in water are limited in comparison to provincial rights, this head of jurisdiction is not directly employed very frequently. ${ }^{64} I$ hope to show later, however, that it does provide an extremely important indirect justification for federal involvement. Section $92(10)$ (c) contains a very unusual provision. It allows Parliament to usurp legislative competence over any public work in Canada simply by declaring the work to be for the "general advantage of Canada or . . . of two or more of the provinces." This power has been used extensively in the past to create federal jurisdiction over a wide range of works, including many connected with water and water power. It has fallen into disuse in recent years, however, because of the serious political risk it would involve for federal politicians in this era of aroused provincialism. ${ }^{65}$ "Indians, and land reserved for Indians" are within federal competence by virtue of section 91(24). ${ }^{66}$ Control over irrigation projects could be based on section 95, "Agriculture in all or any of the provinces," and prohibition of water pollution might be founded on the federal "Criminal law" power under section $91(27) .{ }^{67}$

One of the most heavily relied-upon bases for federal involvement in provincial water management is also the most questionable from a constitutional point of view: the so-called federal "spending power." The federal government provides grants, loans, and other assistance to a variety of water projects within provincial competence, and, by imposing conditions on such offers of assistance, frequently plays a very influential role in their development. How can this type of cooperative federalism be justified constitutionally? It is not enough to say that because the federal Parliament may by section 91(3) raise money "by any mode or system of taxation," it may use that money to finance pro-

62 Fisheries Reference, supra, n. 5; Fish Cannery Reference, [1930] A.C. 111.

63 A.-G. for B.C. v. A.-G. for Canada, supra, n. 21; A.-G. for Canada v. A.-G. for Quebec, supra, n. 18.

B4 It does mean, however, that Parllament has legislative Jurisdiction within national parks: Cherry v. Smith, [1933] 1 W.W.R. 205; R. v. McMahon (1964), 44 D.L.R.(2d) 752.

os $A$ thorough study of the declatory power, together with a chart listing previous uses of the power, will be found in $\mathrm{K}$. Hanssen, The Federal Declaratory Power Under the British North America Act, prepared for the University of Manitoba Interdisciplinary Study on Water Resources in Western Canada, and soon to be published in ciplinary Study on Water Res

o6 See Lysyk, Unique Constitutional Position of the Canadian Indian (1967), 45 Can. Bar Rev. 513.

67 Of course non-prohibitory pollution control measures (such as loans to finance sewage treatment plants, for example) would have to be justlfled in some other way. The "spending power" may Justify Central Mortgage and Housing Corporation loans to municipalities for sewage works. 
jects that would otherwise be within provincial jurisdiction. The fallacy of this reasoning was pointed out by a dictum of Lord Atkin in the Unemployment Insurance Act Reference ${ }^{68}$ more than thirty years ago:

... assuming that the Dominion has collected by means of taxation a fund, it by no means follows that any legislation which disposes of it is necessarily within Dominion competence.

It may still be legislation affecting classes of subjects enumerated in section 92 , and if so would be ultra vires.

If the federal spending power is to be upheld, it must be on the basis of legislative jurisdiction to pass the statute spending the money, not raising it. Most writers feel that such authority exists, either in the prerogative right of the federal Crown to use its assets as it pleases, or in Parliament's express powers in relation to the "peace, order and good government" of Canada, or "public . . . property."69 Others, however, feel that Parliament's spending power is limited to matters within its direct legislative scope, ${ }^{70}$ and the question has yet to be authoritatively settled. ${ }^{71}$

The final category of federal legislative competence to be examined is the controversial peace, order and good government clause, which precedes the specific enumeration of Parliament's powers in section 91 . It is well established that this provision allocates to Parliament the residuum of legislative powers not given specifically to either the provincial legislatures or the federal Parliament. There is no consensus, however, about the extent of the powers thereby created. The dispute concerns matters which, in another context, would be within provincial jurisdiction but which, because they happen to be of national significance, are regarded as beyond the aegis of provincial legislatures, and therefore within the "peace, order and good government" power of Parliament. This technique of creating federal jurisdiction over national questions of all types was employed rather freely by the courts at one time, but then was severely curtailed in a series of Privy Council decisions restricting its operation to situations of temporary national emergency, such as war. ${ }^{22}$ As a result of this development, constitutional lawyers have a tendency to overlook the peace, order and good government power when studying problems like the one we are examining. But the power is not dead; it has been quietly licking its wounds and regaining strength, and in recent years it has begun to reassert itself as a source of federal jurisdiction, even where no emergency exists. ${ }^{73}$ It is once more possible to

$68[1937]$ A.C. $355,366$.

69 See, for example, G. V. La Forest, The Allocation of Taxing Power Under the Canadian Constitution 36-41 (1967). Professor La Forest observes that "The result achieved is a rough judicially umpired compromise between a virtually all-powerful central government in a nominally federal state and a loose confederacy. To put it another way, the Dominion may by combining the taxing and property powers influence, and powerfully influence, but it cannot directly regulate." His further comment that without this federal spending power Canada would lose the "capacity to function as a modern state" seems exaggerated, however. It is possible to envision a "modern a modern state" seems exaggerated, however. It is possible to envision a "modern state" organized on federal lines in which matters which could be effectively dealt
with at the provincial level would be left entirely to the provinces, and financed by them with the assistance only of unconditional equalization payments to the less wealthy provinces.

70 See, for example, 2 Report of Royal Commission on Constitutional Problems (Quebec)

71 See D. V. Smiley, Conditional Grants and Canadian Federalism (1963). In the United States, the question has been settled in favour of the federal spending power: Massachusetts v. Mellon (1923), 262 U.S. 447.

72 The story is told in Laskin, "Peace, Order and Good Government" Re-examined (1947). 25 Can. Bar Rev. 1054.

73 The "emergency doctrine" was repudiated in A.-G. for Ontario v. Canada Temperance Federation, [1946] A.C. 193, although it has re-appeared on occasion since then. Recent evidence of the renewed vigor of the power can be found in Johannesson $v$. West St. Paul, [1952] 1 S.C.R. 292; Porter v. The Queen. [1965] 1 Ex.C.R. 200; and Munro v. Paul, [1952] 1 S.C.R. 292; Porter v, The Queen, [1965] 1 Ex.C.R. 200; and Munro v. uranium mining, which could not be appropriately administered at the provinclal 
predict that if a subject matter of legislation has great national significance there is a reasonable likelihood that the courts will place it within federal jurisdiction for that reason.

Would this clause have any relevance to the administration of provincial waters? I believe that it would; not just because water resources are important to the nation (it is not the importance of a matter that moves it from provincial to national control, it is the fact that it cannot be dealt with in the manner desired at the provincial level), and not because it would be desirable to administer water uniformly across the country (water problems in Quebec are quite distinct from those in Saskatchewan, and call for a different approach), but because it would not be possible for any province by itself to create the kind of allembracing, multi-use administrative agency that most resource administrators seem to think would be ideal. If the British Columbia government, for example, desired to create a Fraser River Authority capable of planning and administering the total development of that river, it would discover that it could not give the Authority power to deal with problems of navigation, or fishing seasons, and that federally-incorporated companies, at least those engaged in activities under federal control, would in some cases be immune from the Authority's regulations regarding pollution, etc. Most observers seem to have concluded from these facts that omnicompetent basin authorities are therefore constitutionally impossible in Canada. I submit, on the contrary, that this is exactly the type of situation that the "peace, order and good government" clause is capable of covering, and that if it wished to do so, Parliament would have the constitutional capacity to create the type of multi-purpose basin authorities that the provinces cannot create. I cannot deny, however, that it would require a federal government of unusual political courage to take such a step unilaterally.

\section{Federal-Provincial Co-operation}

With legislative power over water divided, and with the federal government unlikely for political reasons to test the full extent of its jurisdiction, the desirability of federal-provincial co-operation is obvious. And, in fact, federal and provincial resource administrators have discovered many different ways to cooperate. The purpose of this section is to point out that if the administrators are serious in their oft-expressed belief that water could be most effectively administered by omnicompetent basin authorities, this result can also be achieved through co-operation.

This could be accomplished by mutual delegation of their powers over water to agencies created by the provincial or federal legislatures. Although delegation of constitutional powers from one level of legislature to another is not valid, ${ }^{i 4}$ delegation to an administrative body, even one created by another legislature, has long been regarded as permissible. ${ }^{i 5}$ Constitutionally, then, nothing would stand in the way of a Fraser River Authority, created by British Columbia legislation and given plenary powers by provincial and federal statutes.

level, has been judicially recognized on the basis of the peace order and good government power: Pronto Uranium Mines v. Ontario Labour Board (1956), 5 D.L.R. (2d) $\mathbf{3 4 2}$ (Ont. H.C.).

74. Nova Scotia Interdelegation Case, [1951] S.C.R. 31.

is Prince Edward Island Potato Marketing Board v. Willis, [1952] 2 S.C.R. 392. 


\section{Inter-Provincial Waters}

Where waters cross or define provincial borders, the legislative powers of the provincial legislatures are considerably less extensive than where purely internal waters are concerned. I pointed out earlier that in my opinion the exercise by one province of its proprietary rights over water is subject to the rights which by "inter-provincial common law" belong to other provinces which share the same water, and that no provincial statute can validly be passed which detrimentally affects rights outside the province.

In theory, most of the problems that result from this divided jurisdiction could be solved by co-operation. So far as the day-to-day administration of these waters is concerned, much is already being achieved by co-operation, and there would be no constitutional obstacles to going so far as to create omnicompetent inter-provincial basin authorities by delegation from Parliament and the appropriate provincial legislatures, if it were thought expedient to do so. Inter-provincial disputes over allocation of water, pollution of shared water, etc., could theoretically also be settled by inter-provincial agreement. In practice, however, there are many reasons why co-operation fails to produce satisfactory results, particularly with respect to proprietary disputes between provinces. The bargaining process only succeeds when the negotiating parties each has substantial bargaining strength-something the other party wants. All too frequently in water rights disputes, one party-usually the upstream province-holds most of the trump cards. It is this kind of situation that has created the prolonged deadlock in the prairie provinces over the respective rights of the three provinces to the waters of the Saskatchewan River. ${ }^{78}$ Another difficulty with relying on a negotiated settlement is that the result is likely to be a compromise, reflecting the political power of the parties, rather than a just solution to the problem. ${ }^{77}$

The legislative competence of the federal Parliament over interprovincial water is considerably greater than over internal water.

Section 92 (10) (a) creates federal jurisdiction over ". . . ships, railways, canals, telegraphs, and other works and undertakings connecting the province with any other or others of the provinces ..."78 The words "works and undertakings" have been construed broadly, ${ }^{79}$ with the result that there is federal jurisdiction over a wide range of projects and activities having some genuine inter-provincial element, however small. ${ }^{80}$ Where such an element exists, the courts have been reluctant to sever the intra- and inter-provincial aspects, and have tended to place Parlia-

70 Manitoba's only bargaining strengths against the upstream provinces would seem to be (a) the threat of resort to public opinion, (b) the promise of some compensating benefit in return for the water (perhaps in the form of electric power) and (c) the hope that if the matter were litigated, the court would recognize rights in downhope that if the matter were litigated, the court

i7 Mackenzle, loc. cit. supra, n. 4, at 509, says: "An agreement arrived at through the resolution of a dispute between parties usually amounts to a compromise which frequently makes concessions to local or state interests at the expense of an overall plan of development. The parties are interested less in the value of the overall project than they are in getting the largest share of benefits for themselves." Two American than they are in Betting the largest share of benefits for themselves." Two American cessful in water development and management": Fox and Craine, "Objectives and Organizational Arrangements for Multi-Purpose Development and Management of Water Resources," 1 Resources for Tomorrow Background Papers, 281 (1961).

78 Section $91(13)$, "Ferries . . . between two provinces," is also relevant, but seems redundant.

70 See A.-G. for Ontario v. Winner, [1954] A.C. 541.

$80 \mathrm{~A}$ trucking operation with only six per cent of its business extending beyond the province was held to be an inter-provincial undertaking for this purpose in Re Tank Truck Transport Ltd. (1961), 25 D.L.R. (2d) 161 (Ont. H.C.). 
ment in charge of the entire operation. ${ }^{81}$ While Parliament's jurisdiction under the so-called "declaratory power" in section $92(10)$ (c) is limited to physical "works," this power applies as well to any inter-provincial "undertaking," which is capable, in my opinion, of being interpreted widely enough to include arrangements for the management or allocation of water in an inter-provincial stream. It should also be mentioned that this head of jurisdiction is not restricted to inter-provincial waters; it applies to any work or undertaking with an inter-provincial characteristic. Thus, a hydroelectric power plant making use of strictly internal water could still fall under federal jurisdiction if it were linked to a power grid extending beyond provincial boundaries. ${ }^{82}$

Some writers have suggested that Parliament's power over "the regulation of trade and commerce" by virtue of section 91(2) might also be invoked with respect to some inter-provincial water problems, especially transactions between provinces which treat water as an exportable commodity. ${ }^{83}$ In view of the very restrictive manner in which the power has been interpreted over the years, however, I am dubious that the courts would regard such transactions as relating to trade and commerce.

There is a very good chance, on the other hand, that the courts would find the peace, order and good government clause applicable to interprovincial waters, whatever they might feel about its applicability to internal waters. It might, for example, be held that the power to create a single authority to administer an inter-provincial river falls into the federal residuum because it would be manifestly beyond the competence of any provincial legislature. ${ }^{84}$ However, even if the court were not prepared to go that far, I think it is beyond doubt that the peace, order and good government clause at least empowers Parliament to make laws relating to the settlement of disputes between provinces over water rights (or other problems for that matter). Unlike the American and Australian constitutions, ${ }^{85}$ the British North America Act has no express provision relating to the settlement of disagreements between provinces. If there is any subject which is beyond the legislative competence of any individual province, it is the settlement of inter-provincial controversies, and if ever a problem had national significance in a federal nation, this has. In my opinion, therefore, Parliament has the constitutional power to give a court compulsory jurisdiction over such disputes, ${ }^{86}$ and to determine the principles upon which they are to be settled. ${ }^{37}$ Those who feel that it would be unwise for Parliament to exercise this jurisdiction should reflect on the alternatives: judicial decision based on the judiciallycreated "inter-provincial common law" mentioned earlier; negotiated settlement, subject to the interminable delays and other difficulties referred

81 See, for example, The Queen v. Board of Transport Commissioners (1968), 65 D.L.R. (2d) 425 (S.C.C.).

82 British Columbia Power Corporation Ltd. v. A.-G. for British Columbia, supra, n. 55.

83 Mackenzie, op. cit. supra, $n$. 4, at 511. A fuller examination of the problem can be found in Turnbull, op. cit., supra, n. 4 , at 17.

84 The Australian River Murray Commission might provide an interesting model. Mackenzie, id., at 508, describes it as follows: "The Commission consists of four members, one appointed by the Commonwealth and one by each of the three states. A quorum to transact the Commission's business requires the presence of all four commlssioners and each commissioner has a veto. If the commissioners are unable to agree for a period of two months.... an arbitrator may be appointed whose decision is binding and conclusive." (Italics added).

85 The courts are expressly given jurisdiction over inter-state disputes by the Constitutions of both the United States (article III, section 2) and Australia (section 75 (IV) ).

86 Laskin, op. cit. supra, n. 4 at 222, disagrees.

87 The United States Supreme Court enforced a federal act allocating water in an inter-state river between the states in Arizona v. California (1963), 373 U.S. 546. 
to above; or failure to settle, with consequent "self-help" action by individual provinces. As Gisvold has said, "the desirability of having interprovincial disputes solved by agreements ought not to prevent the establishment of a general jurisdiction to entertain them."

\section{International Waters}

The respective rights of Canada and the United States in waters which cross or define the international boundary are beyond the scope of this paper. There are, however, constitutional problems, concerning the roles of the federal and provincial governments, which arise with respect to international waters.

Constitutional problems in the field of international relations are of two major types: those relating to international negotiations, and those relating to the implementation of international obligations by internal laws.

Until recently, it was generally assumed that international negotiation was an exclusively federal matter, but the wave of provincialism that has swept the country in the past few years has led to a re-examination of this assumption. The British North America Act offers no direct assistance, because an autonomous international role for Canada was not contemplated when it was written. Those who support a provincial role in international matters rely on the undeniable fact that the undefined residue of executive powers known as the royal prerogative has been held to have been divided between the federal and provincial governments on the same basis that legislative powers were divided. ${ }^{39}$ Therefore, they say, the power to enter into international treaties (which is an executive function) is divided between the federal and provincial governments according to whether the treaty concerns a matter inherently within federal competence or provincial competence. This would lead, in the field of water resources, to the conclusion that since water rights within a province belong to the province, the provincial government may negotiate and conclude international treaties concerning those rights. Most writers reject this argument, however. ${ }^{90}$ The fatal flaw in the argument, in my opinion, is the failure to recognize that if a provincial body of water has a substantial international aspect, either because it crosses the international boundary, or, perhaps, simply because it is made the subject of international negotiations, it becomes a matter of national significance, and cannot be treated as being solely within provincial competence. I acknowledge that there is nothing to prevent the government of a province entering an agreement on any subject with a foreign government, ${ }^{01}$ if the foreign government is willing to do so, and that such an agreement could have legal force in the sense of being judiciable in the courts of the foreign nation, or in some mutually agreed arbitral tribunal. However, such agreements would not bind Canada at international law, and would probably not be judiciable in the International Court of Justice, since its jurisdiction is restricted to disputes between "states." ${ }^{\text {" It }}$ is even

88 Op. cit. supra, n. 4, at 106.

89 Bonanza Creek Gold Mining Co. Ltd. v. The King, [1916] 1 A.C. 566, 579-80.

90 The most complete recent discussion is Morris, The Treaty-Making Power: A Canadian Dilemma (1967) 45 Can. Bar Rev. 478.

91 It is concelvable. I suppose, that the courts might entertain an action for a writ of prohibition against a provincial officer who did so, but it is improbable in my opinion.

92 Statute of the International Court of Justice, Article $34(1)$. 
possible that the foreign country's negotiations with a province against Canada's wishes would constitute a breach of international law. Moreover, the province would have difficulty implementing the agreement, which brings us to the second category of constitutional problem in this field.

The power to implement treaties by internal legislation was unequivocally given to the federal Parliament by section 132 of the British North America Act, ${ }^{93}$ but the operation of that section is unfortunately limited to treaties entered into between the British Empire and foreign countries, no other type of treaty being in contemplation in 1867. A 1937 decision of the Privy Council ${ }^{94}$ angered those of centralist persuasion by declaring that treaties entered into by Canada as an independent nation can only be implemented by the level of legislature having inherent jurisdiction over the subject matter of the particular treaty. This decision has been hotly criticized, both because of alleged inconsistency with a previous Privy Council holding, and for policy reasons. It is unlikely to be directly overruled by the Supreme Court of Canada, ${ }^{95}$ but it is, in my opinion, highly probable that its practical effect will be avoided by holding that the fact a treaty deals with a certain subject is strong evidence that the subject is of national concern, and therefore does not fall within the inherent jurisdiction of the provinces. ${ }^{90}$ But whatever the effect of treaties may be in classifying these matters, I hope to show that the international aspect of international waters is a subject inherently within federal jurisdiction, and therefore beyond the legislative competence of the provinces. ${ }^{97}$

The constitutional basis for federal jurisdiction over international waters is twofold. First, section 92(10) (a) gives Parliament control over "works and undertakings ... extending beyond the limits of the province,"98 and international water management schemes would in my opinion be undertakings extending beyond provincial limits. Second, as I have indicated above, I also believe that the peace, order and good government clause is appropriate here, because international waters are matters of national significance. Some might question whether this constitutional power is broad enough to allow the federal government to extinguish provincial proprietary rights in accordance with some treaty, but it seems to me that if Parliament may do so in connection with its jurisdiction over national railways, ${ }^{98}$ it should be able to do so for this purpose as well.

The provinces may, of course, legislate regarding the purely internal aspects of international waters. This is acknowledged by the wording

93 "The Parliament and government of Canada shall have all powers necessary or proper for performing the obligations of Canada or of any province thereof, as part of the British Empire, towards forelgn countries, arising under treaties between the Empire and such foreign countries." An important example of federal legislation passed pursuant to this power is The Boundary Waters Act, S.C. 1911, c. $\cdot 28$.

04 Labour Conventions Reference, [1937] A.C. 326 .

95 The possibility of doing so was hinted at by Chief Justice Kerwin, however, in Francis v. The Queen, [1956] S.C.R. 618, 621.

96 See Lederman, "Legislative Power to Implement Treaty Obligations in Canada," In Aitchison, Political Process in Canada, 171 (1963).

97 Laskin, op. cit. supra, n. 4, at 220 , seems to disagree: "it is fairly clear that a Province may enter into a water management arrangement with a neighbouring State of the United States which, although not binding in any international or even domestic sense. would entail local legislation and administration by each jurisdiction in pursuance of the common arrangement." The case which he cites in support of this proposition did not, however, involve an international agreement.

98 Sections 92(10) (b), "lines of steam ships between the province and any British or foreign country," and 91 (13), "ferries between a province and any British or foreign

oo A.-G. for Qüebec v. Niplssing Central Rallway, supra, n. 32 . 
of the federal International River Improvements Act, ${ }^{100}$ which limits its application to activities having trans-boundary ramifications.

\section{THE FUTURE}

The foregoing discussion has dealt exclusively with the question of what powers the federal and provincial governments may constitutionally exercise. It may be summarized by saying that neither level of government alone has the constitutional power to exercise complete control over water resources, although the federal authorities have a greater potential power in this regard than the provincial authorities. It may be worth while before concluding to turn for a moment to a different question: what role ought the federal government to play in the future?

Central to the theory of federalism is the principle that only those tasks of government which are best handled on a national basis should be allocated to the federal authority; the rest should be handled locally. In Canadian water resource administration this principle does not appear to have been honored. On the one hand, the federal government is very heavily involved (by means largely of its spending power) in countless activities which do not require a national approach, while on the other it has avoided dealing with certain problems (such as settlement of inter-provincial disputes) which can only be effectively dealt with by federal action.

I believe that the federal government should withdraw from all programs which can be handled as effectively at a lower level. I do not mean to imply, however, that all such relinquished jurisdiction should then fall into the hands of provincial governments. Some of it would, of course, but there are, as we have seen, some substantial constitutional impediments to the exercise of provincial powers in this field, and, in any event, provincial control is no more appropriate to many of these questions than federal control. The natural units of administration in most cases would seem to be the river basins, ${ }^{101}$ which do not co-incide with provincial boundaries. As I have indicated above, creation of a basinoriented system of water resource management would be entirely feasible under the existing constitution, through delegation by both federal and provincial legislatures of administrative (not just advisory) powers to basin authorities. There would, I acknowledge, be difficult problems concerning the relationship between the various basin authorities, ${ }^{102}$ the method of financing their activities, and so on, but I am convinced that they would be capable of solution within the existing framework.

In other areas, it seems to me that the federal government should play a more active role in water management. Perhaps the most important of these areas at present would be the establishment of procedures and principles governing inter-provincial water rights disputes, to ensure a greater degree of predictability in such matters than is possible under "inter-provincial common law." If the federal government were to relinquish much of its administrative activities to basin authorities in the future as I have suggested, it could still perform many valuable

100 S.C. 1955, c. 47.

101 See 2 Clark, op. cit. supra, n. 11, at 294 ff.; Teclaff, The River Basin in History and Law (1967); Patterson, op. cit. supra, n. 2, at 246; Rowley, "The Saint John River Basin," Resources for Tomorrow Background Papers 311, 322 (1961).

102 See Fox and Craine, op. cit. supra, n. 77, at 293. 
functions. International arrangements, guarantees of financial equality among basins, inter-basin liaison, and maintenance of a pool of technical expertise which could advise basin authorities on a loan or rental basis, would be some of the possible types of federal involvement.

The administration of Canadian water resources will continue in the foreseeable future to involve a blend of federal and provincial activities, but there is no constitutional reason why it should continue to be hampered by the confusion and poor co-ordination that marks the present situation. 